\title{
Relationship between Corporate Social Responsibility (CSR) and Internationalisation Strategies: A Descriptive Study in the Spanish Context
}

\author{
José-Luis Godos-Díez *, Laura Cabeza-García and Cristina Fernández-González \\ Department of Business Administration, Universidad de León, 24071 León, Spain; \\ laura.cabeza@unileon.es (L.C.-G.); cferng11@estudiantes.unileon.es (C.F.-G.) \\ * Correspondence: jlgodd@unileon.es; Tel.: +34-987-293-593
}

Received: 9 July 2018; Accepted: 27 September 2018; Published: 1 October 2018

\begin{abstract}
Corporate social responsibility (CSR) is a voluntary competitive strategy that is based upon social, economic, and environmental improvement in which the organisation is involved. Internationalisation, a type of corporate strategy, is a set of processes that help companies to expand globally to achieve the aim of improving their competitive position. Both of the strategies have become more important due to ever increasing globalisation, whose consequences modify economic and business environments, thus causing them to be more dynamic and competitive. This directly affects business management, thus companies increasingly consider the opinion of society, attempting to gain stakeholders' trust through effective CSR management. In this context, this paper aims to analyse CSR and internationalisation strategies and their possible connection from a theoretical viewpoint. From a practical viewpoint, the relationship between both strategies is analysed while using a sample of Spanish listed companies.
\end{abstract}

Keywords: CSR; Internationalisation; Strategic management

\section{Introduction}

In the current globalised market, companies must use strategic techniques and tools both domestically and internationally in order to improve their long-term competitive position. So, a sound strategic plan for decision making is required if a company is to have a higher probability of success in meeting its goals. Among the strategic decisions are corporate social responsibility (CSR) and internationalisation. Numerous factors influence companies' decisions in these strategic areas. For CSR, general interest in these policies has been growing, which is perhaps partly due to the economic crises in many countries, or growing environmental pollution and destruction. Our society is increasingly concerned about its social, environmental, and economic surroundings, while supporting responsible consumption and respect for human rights. As a result, companies have felt obliged to improve their CSR policies and actions. Company managers frequently promote the role of their employees as carers for society and the environment, supporting their commitment and bringing credibility to their brand, in order to find the most appropriate competitive strategy (Guerras and Navas 2015).

Globalisation is one of the most influential factors to consider when developing an internationalisation strategy as the global economy is experiencing one of the most dynamic moments in its history, with the unification of markets, standardisation of products, and new communication channels. A growing number of companies are losing their fear of breaking into new markets; internationalisation has become one of the main routes for small and medium enterprises (SMEs) growth, and, due to this, commercial relationships between different markets have improved (Nummela et al. 2005). 
Given this context, the purpose of this paper was to analyse the relationship between CSR and internationalisation strategies from a theoretical and descriptive point of view, while using a sample of companies listed on the Madrid Stock Exchange General Index (Índice General de la Bolsa de Madrid; IGBM). We would like to contribute to the literature from a theoretical point of view, by reviewing existing work and identifying the main arguments that might support the relationship between both concepts. We identified factors, like higher visibility or availability of funds, which can make internationalisation promote socially responsible conduct. Other aspects, like good reputation or stakeholder-related knowledge, can help firms with high levels of CSR to develop international strategies.

To the best of our knowledge, limited empirical research simultaneously focusing on both issues has been published (Aguilera-Caracuel et al. 2014; Campbell et al. 2012; Mithani 2017; Zeng et al. 2013), especially for Spain, which is a relevant context to study, as CSR and internationalisation strategies of Spanish firms have been increasing (Correa-López and Doménech 2012; Forética 2015). Notably, Aguilera-Caracuel et al. (2011) analysed the influence of internationalisation on CSR from the environmental point of view while using a sample of Spanish firms in the food industry. Thus, we carry out a descriptive analysis with the aim of adding empirical evidence to this strand of literature. More specifically, (1) we focus on Spanish listed companies, which is relevant due to their large size and considerable impact in those regions or places where they are located; (2) we use a more comprehensive CSR index, which includes more than only environmental issues; and, (3) we integrate different measures of internationalisation according to previous empirical studies.

The remainder of the article is structured as follows: the next section presents the concepts of CSR and of internationalisation, and their strategic relationship. The data, methodology, and results are described in the third section, and the final section provides the principal conclusions.

\section{CSR and Internationalisation}

\subsection{CSR: Concept and Characteristics}

In the business administration field of research, the role of the company in society is being debated. In general, this debate has developed drawing upon stakeholder theory insights (Donaldson and Preston 1995; Freeman 1984; Freeman et al. 2010). In this context, CSR is considered to be the most relevant and/or common concept dealing with companies' social issues (Carroll and Buchholtz 2006; Wood 2010). CSR has moved on from a narrow notion to a wide-ranging and complex concept, increasingly related to companies' decision-making processes and consistent with public expectations of the business community (Carroll 1999; Cochran 2007).

Carroll (1991) significantly contributed to the research into the history of CSR ${ }^{1}$. According to his four-level pyramid diagram, each level depends on the others (Carroll 1991), making CSR a complex and multidimensional concept: (1) Economic responsibilities are at the base of the pyramid, representing the production of goods and services that consumers need and want. The company must achieve a reasonable degree of profitability in the process of production and sale of its goods or services; (2) Legal responsibilities are the expectation of society that companies comply with the law and state regulations in force in the geographic area where they operate and applicable to their kind of business; (3) Ethical responsibilities are society's expectations that the company will conduct its business while trying to behave correctly, fairly, and reasonably, meeting certain ethical standards, and to minimise harm to the different stakeholders in society; and, (4) Philanthropic responsibilities are society's expectations that companies should be voluntarily involved in activities that foster good

1 In spite of its relevance, Carroll's model has been rationally criticised by several authors including Key (1999) and van Oosterhout and Heugens (2009), among others. 
corporate citizenship. Such actions include the involvement of companies in programmes that promote social welfare and improve citizens' quality of life.

Many different definitions of CSR have been introduced, from both academic and professional arenas. However, no definition has been universally accepted (Matten and Moon 2008; Wan-Jan 2006). Following Dahlsrud (2008), a series of dimensions have been used to characterise the essence of CSR: consideration of economic, social, and environmental issues, stakeholders, and voluntary nature. Notably, the term CSR has often been used to describe both the concept of companies' social responsibilities, and to measure the practices, actions, or measures that are taken by a company on social and environmental issues (Manner 2010). Although there are alternative understandings of CSR linked to externalities (Crouch 2006; Laudal 2011), shared value (Porter and Kramer 2006, 2011), and provision of private public goods (Bagnoli and Watts 2003; Besley and Ghatak 2007), here we used the 'stakeholder definition', meaning that CSR is understood as those discretionary actions taken by a company to promote a social good of some kind, above and beyond the company's own interests and legal requirements (Barnett 2007; McWilliams and Siegel 2001).

We are currently experiencing a change phase in which companies are increasingly committed to achieving optimal socially responsible outcomes, treating each social, economic, and environmental issue as part of their strategy. Until relatively recently, companies did not consider CSR, but simply concentrated on aggressive action in response to their competitors' behavior, without evaluating other factors that might have an impact on their organisation. However, this type of action is being modified by our current social change (Infante 2015). Furthermore, as referenced by Fernández López (2016), companies are undertaking on different social actions depending on their sector and corporate strategy, examining the needs of their stakeholders and their management style (McWilliams and Siegel 2001).

A series of tools exist for assessing good behavior toward different stakeholders that help companies to act in a socially responsible manner. Of the most prevalent, we can point to the following (Gregorio 2013): (1) Codes of ethics: They are rules regulating the behavior of people in a company or organisation. Although contravening an ethical code does not entail legal penalties, compliance with these codes should be obligatory. The main purpose of these codes is to ensure appropriate behavior on the part of the employees in the company; (2) Codes of conduct: They are documents written voluntarily by a company specifying the basic rights it is prepared to honor in its relationship with all of the individuals in the organisation; (3) Management system standards: They enable the company to achieve optimal results in terms of the impact of its activities on society or the environment. The outcomes enable the company to continuously and responsibly improve; and, (4) Social responsibility reports: They are written documents made public by a company, describing its CSR practices with each stakeholder group involved in the business activity, whether they are social, economic, or environmental.

Fernández López (2016) stated that socially responsible behavior plays a part in creating value for a company that is based on the growth of key strategic intangible resources (Surroca et al. 2010; Wang and Bansal 2012), while enabling the efficient use of opportunities to achieve better economic results. The combined impact of CSR and human resources activities, which reinforce desirable behavior, can importantly contribute to generating long-term success in organisations (Sharma et al. 2009). Specifically, responsible behavior produces a series of advantages that benefit all stakeholders (Santonja et al. 2008): (1) Customer loyalty: If the company satisfies its customers, they will want repeat business; thus, efficient and personal service, among others, is highly valued by customers. Consumers are appreciative of those companies that value their clients as a primary component of their business. (2) Improved morale in the workplace and higher productivity: evidenced when employees self-identify as an important part of the organisation and are fairly treated, as they are more highly motivated, which improves labor relations, reinforcing productivity, and achieving better results; (3) Improved perception of the company and its reputation: the economy is currently viewed as the "economy of reputation" as we are surrounded by an economy in which everything is copied, which is why a business' reputation is extremely important as one of its intangible assets that can 
serve as a competitive advantage, as it cannot be copied; (4) Risk mitigation: by implementing codes of ethics and behavior and other types of standard, bad behaviour in companies can be minimised in order to improve relationships with all the stakeholders; and, (5) Encouraging innovation: good CSR practices can help in developing innovative products and services. In addition, the relationship between different stakeholders encourages the search for solutions to potential problems, which creates the right conditions for imaginative ideas and the development of innovative activities and services.

The Howitt report (European Parliament 2013) stated that CSR actions not only benefit society as a whole, but also help companies to compete and remain economically viable in the long term. This positive effect of CSR on financial performance has been supported by some meta-analysis research suggesting that being socially responsible and responding to different stakeholders' needs and expectations results in a competitive advantage, thus improving the company's results (Allouche and Laroche 2005; Margolis et al. 2007; Orlitzky et al. 2003; Wang et al. 2016; Wu 2005). However, there is no consensus on this point, for example, because of the complexity of the CSR concept or the influence of other firm characteristics. Some authors have theoretically argued or empirically found that the positive effect of CSR on performance cannot be generalised and that only the primary stakeholders-focused on CSR activities may increase the financial returns (Barnett 2016; Hillman and Keim 2001). Moreover, the positive CSR-financial performance relationship might be contingent upon other variables. For instance, Wang et al. (2016) underlined the potential effect of firm size, and Surroca et al. (2010) assigned special importance to the presence of other corporate intangible resources.

\subsection{Internationalization: Concept and Characteristics}

Internationalisation is the long-term process through which a company creates a series of conditions that are pre-requisites for expansion into international markets, relocating, and implementing an external strategy (Escuela de Estrategia Empresarial 2014). Thus, a company will have the opportunity to sell its products in new geographic markets beyond its national borders; this is a corporate strategy with the potential to be developed. As well as having a presence in the target country, the organisation will also have to adapt to that country's economy if it is to achieve optimal results (Rodríguez 2015).

Some general internal and external reasons that drive companies to implement a strategy of internationalisation and move beyond their national borders, including the following, depending on their origin (Guerras and Navas 2015). The internal reasons-reasons springing from actions or variables relating to activity within the firm-include (1) cost reductions in the procurement of raw materials or other types of resources that are needed for the company's production process; (2) the search for resources better suited to the organisation or its production process; (3) minimum efficient scale required to achieve the sales volume needed to reach optimal business size; (4) reduction of labor risk by distributing the company's main activities across several geographical areas by seeking to diversify risk; and, (5) full exploitation of resources and capacities that are being under-utilised. The external reasons, which are based on external factors unrelated to the company, include (1) the industry's life cycle, offsetting the phase of maturity in the country of origin; (2) following the client when it has successfully internationalised its activities; and, (3) globalisation of the industry, with the aim of optimizing any opportunities existing in the international market.

Once the reasons or motives driving a company's decision to implement an internationalisation strategy are known, we need to consider two aspects that companies be asking themselves: how to enter the external market and the strategic international competition approach.

With regard to how to enter an international market, entry modes can be divided into three general categories (Pedrero 2014): (1) export, in which production occurs in the country of origin, supplying the other markets in which the company has commercial relations from there; (2) direct investment, consisting of a capital investment by a company in a foreign country (joint venture and owned subsidiaries); and, (3) contractual systems, when certain rights over company assets are ceded 
to a company in the foreign country (franchises or licences). In terms of companies' approaches to international competition, depending on how their activities are organised (Carrión Maroto 2007), they can be divided into the following types (Pla and León 2004; Becerra and Patricia 2010): (1) global strategy, where the product is standardised in order to reduce costs; (2) multi-domestic strategy, focusing on the particular characteristics of each country in which it is operating; and, (3) transnational strategy, whereby the company operates in several countries creating products for global markets that adapt to the demands of the local customer.

Once the forms of entry and international strategies have been selected and introduced, the company should assess its results in terms of its relationship with the foreign market. As Huerta et al. (2015) mentioned, the relationship between internationalisation and business outcomes has been studied by many researchers, because it is viewed as an important dimension in a company's growth (Peng and Delios 2006). There are different perspectives and theories analysing this phenomenon from the theoretical point of view that reach different conclusions using a range of models, but no general consensus has been reached.

Vila and Küster (2015) noted the relationship between internationalisation and business results (profitability, sales margin, etc.) has been researched using secondary sources. For example, Tseng and Yu (1991) reviewed a number of papers that attempted to account for a company's results based on its decision to export or not, as well as the different marketing mix strategies that are used in each country. Most find some kind of connection between going abroad (internationalising) and an increase in financial ratios, although, as Daniels and Bracker (1989) observed, not all of the methods of entering foreign markets are equally profitable in economic terms. However, previous literature has found a positive connection between internationalisation and financial success (Majocchi and Zucchella 2005).

Looking specifically at entry methods, many papers (Aw and Hwang 1995; Aw et al. 2000; Bernard et al. 1995; Bernard and Jensen 1999; Bernard and Wagner 1997; Delgado et al. 2002) found that exporting firms show higher performance levels in terms of productivity, size, survival rates, wages paid, capital intensity, and technological sophistication as compared with non-exporting companies. The economic literature has traditionally offered two complementary explanations for the higher levels of productivity of exporting firms than non-exporters: the self-selection hypothesis, and the learning hypothesis. Both are explained in detail below.

The self-selection hypothesis implies that it is the company's competitive success that triggers it to export. Using this argument, export markets select the most efficient companies from among all potential entrants. Therefore, it is the most productive companies that finally break into foreign markets. The learning hypothesis implies that it is exporting itself that generates competitive success. Companies that export benefit from increases in their productivity from two different aspects. Firstly, the international market, bigger than the domestic market, provides economies of scale by contributing to a significant increase in the use of companies' installed capacity. Secondly, the rate of productivity growth is determined by the learning process that these same companies develop in foreign markets, with information spill overs being the benefit that is most frequently cited in this area (García and Camarero 2008).

In terms of results of empirical studies, Vila and Küster (2015) concluded that companies that have internationalised score significantly higher on average than those that have not (especially net profits). Research conducted by Huerta et al. (2015) confirmed a quadratic relationship between the degree of internationalisation and business results. This may be because companies, at the outset of the internationalisation process, incur higher costs in understanding the market and installing themselves in it, which thus affects their profitability. However, as their degree of internationalisation grows, their results improve. Furthermore, according to this study, the most profitable strategy for entering external markets seems to be to export using specialised intermediaries.

According to García and Camarero (2008), exporting companies should be more productive than those that do not export because they have to be capable of entering these markets and achieving 
a certain level of profitability in order to be able to continue their commercial activity on a regular basis. As such, only the most efficient companies will be capable of overcoming the entry costs that are involved in export markets and of taking on the competition in those markets. Global partnerships, in which partners coordinate their actions to achieve shared international growth, are becoming increasingly important. This type of cooperation is within the reach of any company, so some companies that are in crisis can achieve better results by cooperating with other types of firms in a stronger economic position (González et al. 2013).

Finally, according to García-Canal et al. (2012), the fact that preliminary results in this area have not always been conclusive may be due to the use of different performance measurements, such as the reaction of the capital market (López-Duarte and García-Canal 2007), productivity indicators (Farinas and Martín-Marcos 2007), the Tobin “Q” ratio (Ramirez-Aleson and Espitia-Escuer 2001), other profitability indicators (García and Camarero 2008; Camisón and Villar-López 2010), or, because, on most occasions, only industrial firms are considered.

\subsection{Strategic Relationship between Corporate Social Responsibility and Internationalisation}

Few studies analysed CSR and internationalisation strategies together (Hah and Freeman 2013). The main difficulty in conducting these studies stems from the problems in defining CSR, together with the issue of practice management by companies operating in international markets (Jamali 2010). CSR and internationalisation can be viewed as complementary strategies, since arguments exist for a dual causality, that is, that CSR can affect internationalisation and vice versa. In general, such arguments can mainly be developed drawing upon the resource-based view (Barney 1991) and stakeholder theory (Freeman 1984).

Regarding the resource-based view, organisations are considered to be different from each other in terms of the resources and capabilities that they possess at a given time, as such resources and capabilities are not available to all companies under the same conditions (Barney 1991; Wernerfelt 1984). As such, both strategies, CSR and internationalisation, can help firms acquire and develop valuable, scarce, and imperfectly imitable resources, such as specific market knowledge or reputational capital, which are key to gaining and maintaining competitive advantages (Aguilera-Caracuel et al. 2014).

With regard to stakeholder theory, strategically designed and implemented CSR can address stakeholders' claims and demands, and help to increase firm value (Husted and Allen 2007; Jones 1995). Specifically, the impact of such CSR initiatives may be maximised when they are focused on powerful, legitimate, and urgent groups (Mitchell et al. 1997). This point is particularly more complex for multinational companies (MNEs), as they operate in different markets and face different stakeholders' expectations, values, and scopes (Aguilera-Caracuel et al. 2015).

Specifically, MNEs operating in culturally different markets attempt to improve their social performance for a number of reasons:

\section{Higher Visibility}

Firms with international activity are subject to scrutiny by more stakeholders. Large multinationals are much more exposed to public opinion because of higher awareness of their activities. As such, they run a greater risk of damaging their corporate reputation as a result of their behavior (Hah and Freeman 2013). According Aguilera-Caracuel et al. (2015), international firms face significant pressure from their stakeholders in the locations where they conduct their business to adopt socially responsible behavior and to have a positive impact on society. An improvement in the performance of social or environmental activities strengthens the relationship between the company and surrounding society, although this factor might be very relative, depending on the country in which the institution is operating, since it does not carry the same weight in every country (Garriga and Melé 2004). Thus, the company may behave in two different ways, depending on the country in which it is operating. It may take advantage of countries with more permissive laws to behave more opportunistically, or it 
may do business in different markets to gain greater knowledge, improve transparency, and legitimacy, which will benefit the company in the future (Aguilera-Caracuel et al. 2015).

The company will succeed in forging a competitive advantage when it manages to satisfy all the relevant interest groups (Sen et al. 2006). Thus, an international company that wins this competitive advantage with optimal CSR will improve the credibility of organisations, together with consumer trust, in the destination country (Smith et al. 2010), and hence differentiate itself from its competitors (Maignan and Ralston 2002).

\section{Risk Mitigation}

Against the risk of not being accepted in a new country, given that internationalisation can generate a high level of uncertainty, CSR enables firms to earn legitimacy and reinforce competitive advantage on the international stage.

According to Mithani (2017), when we are examining MNEs, we assume that the internationalisation phase occurs first, followed by the interest in being accepted in the destination country, triggering the development of a CSR strategy (Pant and Ramachandran 2017). MNEs' responses to social demands allow for certain risks to be minimised, since, if the firm succeeds in implementing a good CSR strategy, it will gain greater customer trust and thus improve its results. Moreover, companies need to bear other countries' cultural perspectives in mind when they design their CSR strategies, since, if they do not, there may be errors in CSR practice in the home and destination markets, with a corresponding increase in business risk (Bondy et al. 2012).

Availability of Funds

Internationalisation, as a search for new forms of income, can ensure the continuous generation of resources. MNEs operating in culturally diverse markets may share the costs and benefits of CSR investment across their subsidiaries, so that the firm becomes more socially responsible (McWilliams and Siegel 2001). One of the greatest advantages enjoyed by this type of entity is risk diversification, derived from the internationalisation strategy. Because the firm is operating in multiple markets, a negative impact in one can be offset in another, enabling the entity to achieve a relatively stable economic position and cash flow, so that it can perform social or environmental actions in the markets where it is operating (Dahan et al. 2006; Geppert et al. 2006). The local population will place more trust in MNEs if they demonstrate loyalty to the destination country, with mutual advantages to both the company and the population (Mishina et al. 2012).

Learning and Maximisation of Skills Valuable for Meeting the Expectations of the Stakeholders

According to Madhok (1997), the lack of knowledge about some destination markets causes difficulties when transferring knowledge and skills from the parent company to its subsidiaries and vice versa: if a company wants to respond appropriately and adapt appropriately while using its CSR, it needs to have a solid understanding of the market, as well as of the cultural characteristics of its players. This approach is the only way to achieve an efficient dialogue with each of the parties comprising the market, which involves an improvement in productive efficiency and of processes, international legitimacy, transparency, and reputation. Therefore, doing business in culturally diverse markets helps MNEs to optimise new ideas as they acquire international knowhow (Antonacopoulou and Meric 2005; Barkema and Vermeulen 1998). Aguilera-Caracuel et al. (2015) proposed that market diversity might encourage the development of innovation in the company's environmental management, and, as a result, allow it to implement a more proactive environmental policy.

Scant empirical evidence supports the positive influence of internationalisation on CSR. For example, Aguilera-Caracuel et al. (2011), using a sample of export Spanish firms in the food industry, concluded that a high degree of international diversification encourages these firms to benefit from different environmental competitive advantages from the different regions in which they operate. 
For a sample of 102 United States (U.S.) firms from the chemical, energy, and industrial machinery industries, the percentage of sales in foreign markets and international cultural diversification were found to help firms improve their level of social performance (Aguilera-Caracuel et al. 2014). In addition, a high level of slack financial resources leads MNEs operating in markets with different cultural profiles to improve their corporate social performance (Aguilera-Caracuel et al. 2015). Finally, Campbell et al. (2012), for a sample of countries and focusing on the banking sector, showed that foreign affiliates from more distant home countries are less likely to engage in CSR than affiliates from more proximate home countries. This suggests that, despite increased strategic motivation for CSR, the countervailing effects of distance on the willingness and ability to engage in host-country CSR result in lower CSR investment.

Regarding the influence of CSR on internationalisation, there are two central arguments here:

\section{Good Reputation Associated with CSR}

This is understood as increased legitimacy as CSR can generate benefits that may be used so that the company opens up to new markets leveraging its reputation, resources, and so on. According to Zeng et al. (2013), being perceived as a socially responsible firm enables a company to break into new geographical markets. The main reason here is that a firm's CSR legitimacy signals to customers in the new markets that the firm cares about their interests, and it should contribute to their community (Chow and Chen 2012; Fombrun and Shanley 1990; Spence 1974). Moreover, this positive perception may lead new markets to consider the company as engaged with good product quality and goodwill toward the customer (Wallin Andreassen and Lindestad 1998). Furthermore, this type of socially responsible behavior helps companies to obtain useful resources from the government and other interest groups to promote internationalisation and improve the quality of both society and that of the company that is assessing the option of internationalisation (Eisenhardt and Martin 2000; King and Tucci 2002). As such, there is a positive correlation between a company's CSR and to its success in new geographical markets.

Adapting to New Environments

When a company is accustomed to being in contact with a number of stakeholders, it knows how to respond to all of the demands that can arise in its commercial dealings. This means that it will be better at adapting to the pressures that may arise in its new commercial environment. Bansal (2005) stated that abiding by best practices acquired over the course of years, both in the country of origin and the destination, facilitates cooperation with external agents, and improves response capacity in the event of new requirements, thus leading to better development. Eisenhardt and Martin (2000) argued that proactive environmental strategies are socially complex, specific, and cannot be replicated, so the company can organise its resources so that it can adapt to any change in the commercial environment and deal more fairly with each of the interested parties in its commercial relationships.

Finally, per Keinert (2008), CSR can positively contribute to internationalisation processes, so this should in turn be an international strategy. For a company looking to internationalise, reputation is one of its most important assets, since a solid reputation facilitates entering new markets, helping each of the stakeholders that form part of the company to deposit a high level of trust in it, which is why the adaptation to the new competitive environment is so highly valued.

The empirical study by Zeng et al. (2013), for a sample of Chinese companies, demonstrated that the firm's CSR image had a significant and positive effect on their success when entering new geographic markets. For China, it was also found that exporting SMEs' practice of proactive environmental strategies positively affects their corporate export performance (Chan and Ma 2016). Mithani (2017), for a sample of 190 MNEs and 660 domestic firms, found that in the aftermath of a disaster, the increase in MNE contributions was much larger and less strongly tied to promotional activities than the increase in contributions from domestic firms, and this difference persisted over time. 
Moreover, the performance implication of post-disaster philanthropy was stronger for MNEs than for domestic firms.

Overall, and in line with all the arguments above and the existing empirical findings, we propose the following hypothesis:

Hypothesis 1 (H1): A company's CSR and internationalisation strategies are positively related.

\section{Descriptive Analysis}

\subsection{Sample}

The database used in the analysis presented below included Spanish companies that are listed on the Madrid Stock Exchange General Index (IGBM) on 31 December 2015 (107 companies). Financial and insurance companies were excluded from this initial database due to their special characteristics, such as their specificity from an accounting point of view, their regulation, and structure of this type of market (14 firms). As a result, our research used a population of 93 listed firms.

Given the nature of the research and the absence of secondary data sources for CSR practices, we used a survey to obtain the necessary information for this variable. All 93 firms were sent an online survey between November 2015 and January 2016, with a total of 61 returned questionnaires that could be used in the analysis phase. Those that were asked to complete the questionnaire were the individuals responsible for CSR issues at each company. The response rate was $66 \%$, providing a sample error of $7.55 \%$ and a confidence level of $95 \%$.

Information about internationalisation variables was obtained through the Spanish Securities Market Commission (Comisión Nacional del Mercado de Valores; CNMV) from audit reports providing information about sales distribution and assets for each of the geographic segments where the company does business and has assets. The Sociedad de Análisis de Balances Ibéricos (SABI) database was also consulted for data about companies' exports and the number of countries in which they operate. When information was not available from previous sources, companies were contacted directly by email.

\subsection{Measuring Variables}

To construct an aggregate index for CSR practices (CSR), 19 possible company actions were used (Table 1). Such actions, which included reports, plans, and certificates, among others, were selected as relevant practices for different companies' stakeholders according to previous literature. Specifically, the items were relevant to the extent that they were associated with previously mentioned arguments. For example, offering information on CSR on the company website increases the global visibility of social matters, having different ISOs and OHSAS standards might reduce risk that is associated with quality or environmental issues, and participating in global initiatives, like Global Compact or Global Reporting Initiative, can improve a firm's socially responsible reputation.

These items could take one of two values for each company: 1 if the action in question was present in the company, or 0 if it was not. Thus, to ensure the construct was reliable, Cronbach's alpha coefficient was calculated at 0.801 , which is acceptable, given that it is over the 0.6 minimum, and is justifiable given that the subject being analysed is new and difficult to quantify (Malhotra 1981). As an aggregate measure of the company's CSR practices, the sum of the scores achieved for the 19 items was used.

We also decided to focus on the practices adopted around two of the main stakeholders: employees and shareholders. Both are particularly important, since they are classified as primary groups, understood as those that provide the basic resources for the company's survival (Clarkson 1995). Within these primary groups, internal groups, as in this case, have been shown to exercise a significantly positive influence over the company's performance (Galbreath 2006). 
Table 1. Indicator of Corporate Social Responsibility (CSR) Practices: Possible Actions.

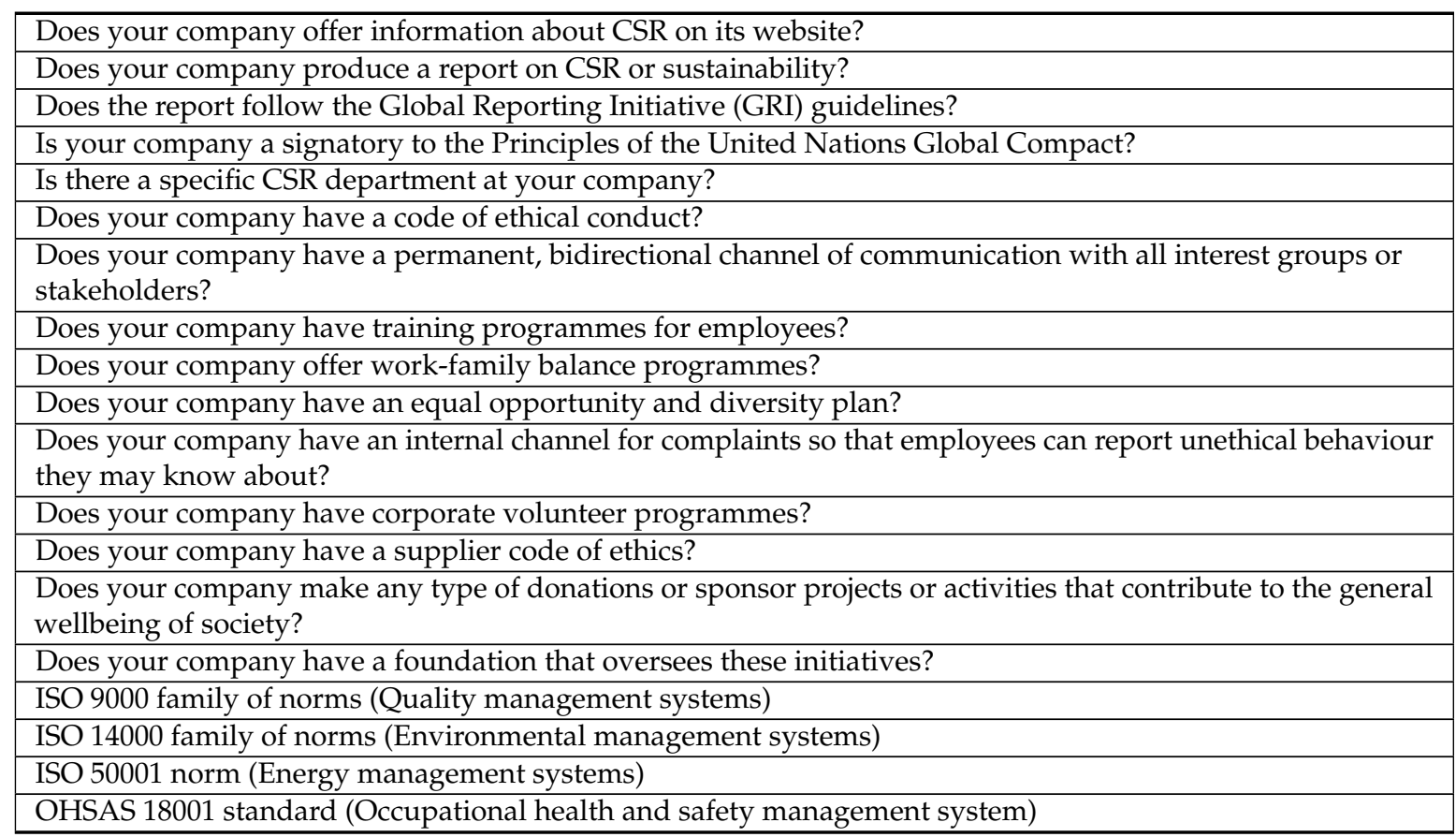

So, we brought together those items that are associated with workers (CSR_EMPLOYEES), and those linked to compliance with general standards and transparency norms, which ultimately denote a commitment to the company's shareholders or investors that can help it to secure funds (CSR_SHAREHOLDERS) (Table 2). In these cases, Cronbach's alpha coefficients were 0.616 and 0.675 , respectively.

Table 2. Indicator of CSR Practices: Employees and Shareholders.

\begin{tabular}{|l|l|}
\hline \multirow{4}{*}{ CSR_Employees } & Does your company have training programmes for employees? \\
\cline { 2 - 2 } & Does your company offer work-family balance programmes? \\
\cline { 2 - 2 } & Does your company have an equal opportunity and diversity plan? \\
\cline { 2 - 2 } & $\begin{array}{l}\text { Does your company have an internal channel for complaints so that employees can } \\
\text { report unethical behaviour they may know about? }\end{array}$ \\
\cline { 2 - 2 } & Does your company have corporate volunteer programmes? \\
\cline { 2 - 2 } CSR_Shareholders & OHSAS 18001 standard (Occupational health and safety management system) \\
\hline & Does your company offer information about CSR on its website? \\
\cline { 2 - 2 } & Does your company produce a report on CSR or sustainability? \\
\cline { 2 - 2 } & Does the report follow the Global Reporting Initiative (GRI) guidelines? \\
\cline { 2 - 2 } & Is your company a signatory to the Principles of the United Nations Global Compact? \\
\cline { 2 - 2 } & Does your company have a code of ethical conduct? \\
\hline
\end{tabular}

We used several variables as our internationalisation proxies, following previous studies. The weighting of foreign sales over total sales was calculated, as were the weight of total assets abroad over the company's total assets, the number of countries in which the company operates, and whether the company has export activity.

Notably, in view of a possible time lapse between of these business decisions and two-way causality, that is, an endogeneity problem, the information on the internationalisation process refers to 2016, whereas the CSR information is from 2015, as indicated above.

In this study, as was the case with Sánchez et al. (2013) and following Sullivan (1994) and other papers (Daily et al. 2000; Lee and Park 2006; Rivas et al. 2009; Sanders and Carpenter 1998), we measured the company's internationalisation along more than one dimension, by both performance and structure. Both of the dimensions represent the depth of a company's participation abroad 
(Thomas and Eden 2004). The performance dimension is normally calculated while using the proportion of sales in foreign subsidiaries over total sales (FSTS) (Geringer et al. 1989). This captures the extent to which international transactions are important in proportion to all transactions and the degree of the company's dependence on foreign markets (Thomas and Eden 2004). The structural dimension is normally calculated using foreign assets as a percentage of total assets (FATA) (Daniels and Bracker 1989). FATA reflects a company's reliance on its investments abroad.

We defined a variable (COUNTRIES) that indicates the international diversification of the company, by considering the number of countries in which each firm is present (Pla and Cobos 2002), as well as a dummy variable (EXPORT_ACT) that takes the value of 1 if the company has export activity (Fernández and Nieto 2005).

\subsection{Methodology}

To check whether there was any relationship between strategic CSR decisions at a competitive level and corporate internationalisation strategy, we conducted a descriptive analysis of sub-samples. The groups were combined depending on whether the company had a high or low level of internationalisation. We calculated the mean value of the sales ratio, the asset ratio, and the number of countries for the entire sample. Next, for each of these variables, those companies with an above-mean score were separated from those with lower scores. Groups were also created using the 'export activity' dummy variable.

Since the samples were not related, we used the Mann-Whitney U Test to determine whether there were significant variances between both subgroups in the different CSR indicators, having previously confirmed the non-normality of these latter variables.

\subsection{Results}

Before starting to consider the statistical contrasts, and, in order to graphically represent the relationship between CSR and internationalisation, a series of scatter plots are presented below, while using the internationalisation proxies that are continuous variables (Figures 1-3). All of them display positive slopes. Furthermore, a positive correlation between the concepts can be observed in Table 3, although the intensity of this correlation varied depending on the indicator used to measure internationalisation. We next present the results of the univariate analysis conducted. First, the economic and financial indicators that were used as variables for internationalisation were considered: sales in foreign subsidiaries as a proportion of total sales (FSTS) and the weight of foreign assets as a proportion of total assets (FATA). In this case, due to the existence of missing values in some of the observations, the sample size dropped to 45 . Cronbach's alpha coefficient values remained within the required parameters, at 0.786 for the CSR variable, 0.6 for CSR_EMPLOYEES, and 0.667 for (CSR_SHAREHOLDERS).

As Table 4 shows, companies with a higher-than-median degree of internationalisation appear to be more socially responsible, whichever internationalisation proxy is considered. To confirm whether the differences found were statistically significant, the non-parametric Mann-Whitney U test was applied for two independent samples, given the non-normality of the variables that were considered. According to the information provided by the median value, the average ranges also indicated a positive association between a higher level of internationalisation and execution of CSR activities. The results, after applying this test on the basis of average ranges, demonstrate that the differences observed are statistically relevant and it cannot be attributed to chance in the case of the FATA indicator, but this was not so when the weight of foreign sales over total sales (FSTS) was considered. Therefore, a positive association exists between the company's reliance on its activity abroad and its execution of CSR actions. 


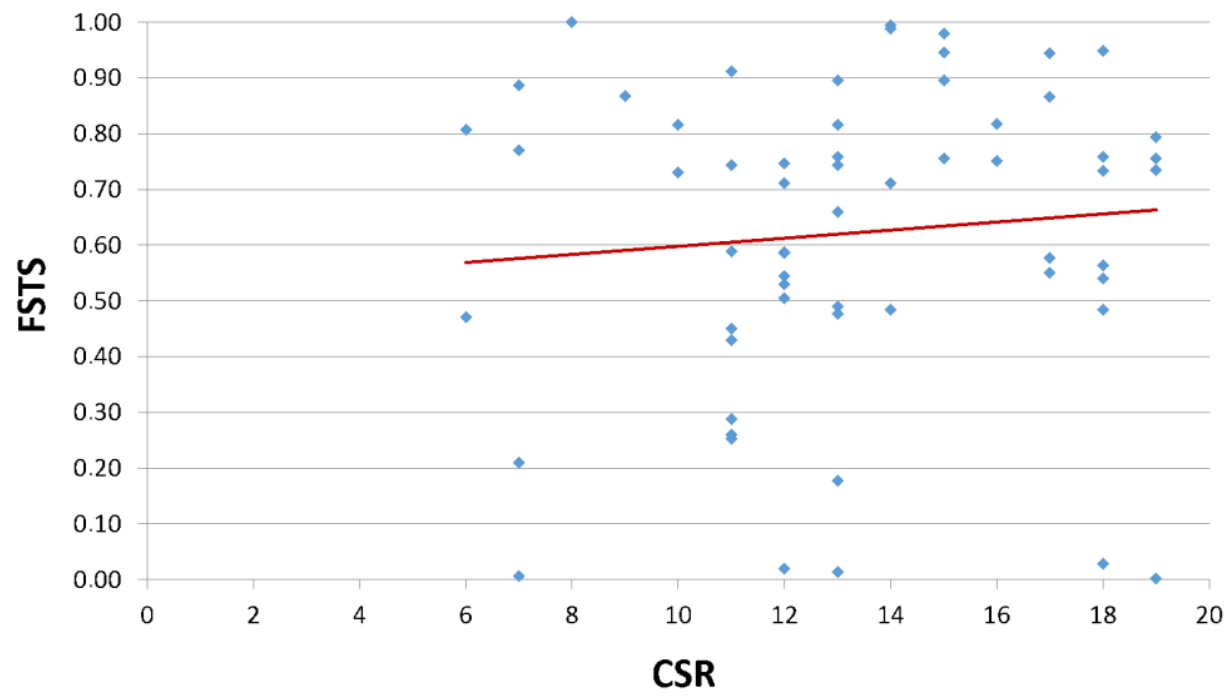

Figure 1. Relationship between CSR and FSTS (Foreign Sales over Total Sales).

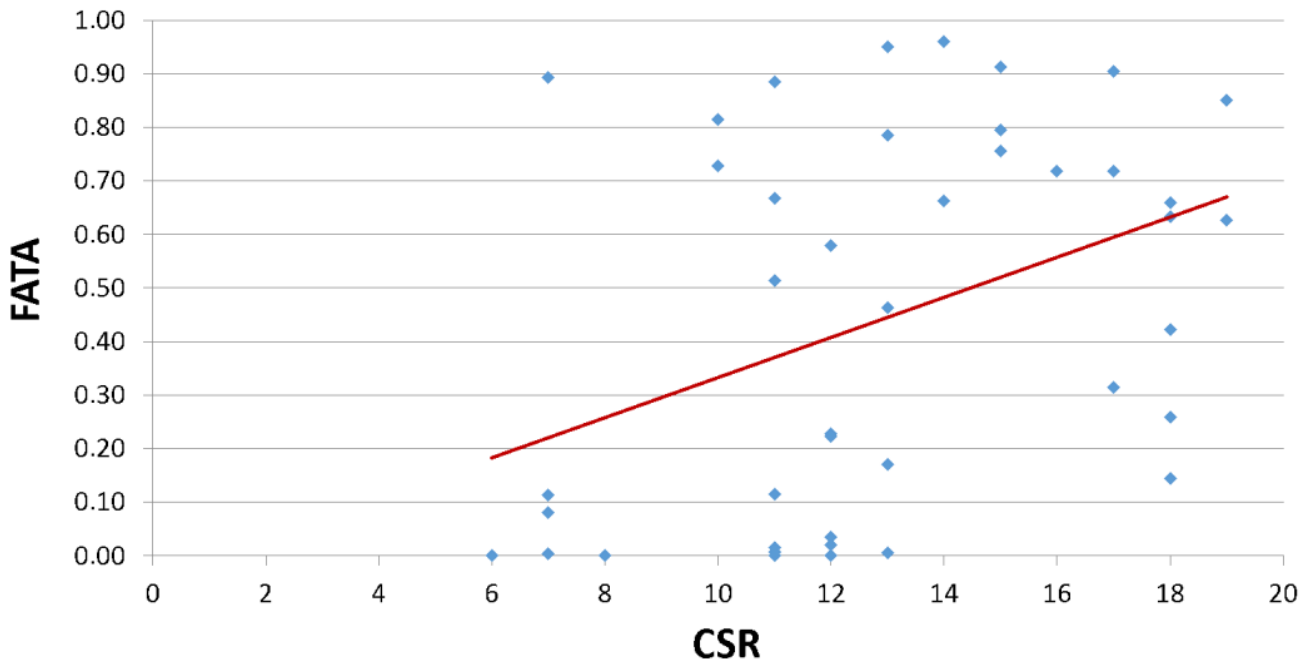

Figure 2. Relationship between CSR and FATA (Foreign Assets over Total Assets).

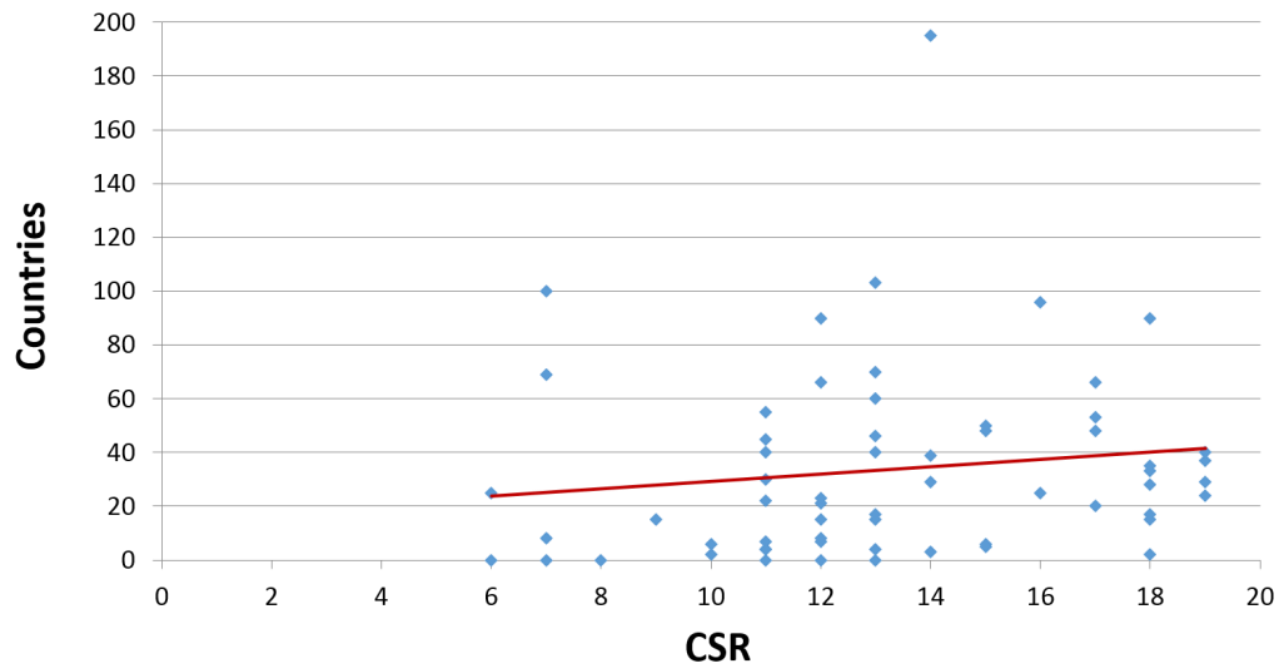

Figure 3. Relationship between CSR and COUNTRIES. 
Table 3. Descriptive statistics and correlation matrix.

\begin{tabular}{|c|c|c|c|c|c|c|c|c|}
\hline Variable & Mean & S.D. & $\%^{a}$ & 1 & 2 & 3 & 4 & 5 \\
\hline 1. CSR & 13.23 & 3.57 & & 1 & & & & \\
\hline 2. FSTS & 0.62 & 0.27 & & 0.09 & 1 & & & \\
\hline 3. FATA & 0.44 & 0.34 & & $0.38 *$ & $0.52^{* *}$ & 1 & & \\
\hline 4. COUNTRIES & 33.61 & 34.91 & & 0.14 & 0.17 & 0.02 & 1 & \\
\hline 5. EXPORT_ACT & & & 90.16 & $0.35^{* *}$ & $0.30 *$ & 0.34 * & 0.32 * & 1 \\
\hline
\end{tabular}

Table 4. Comparative analysis of CSR and Internationalisation (I).

\begin{tabular}{|c|c|c|c|c|c|c|c|}
\hline \multicolumn{8}{|c|}{ Panel A: Internationalisation as \% Sales (FSTS) } \\
\hline \multirow{2}{*}{ Variables } & \multicolumn{3}{|c|}{ High Internationalisation } & \multicolumn{3}{|c|}{ Low Internationalisation } & \multirow{2}{*}{ Mann-Whitney U } \\
\hline & Mean & Median & $\mathbf{A R}^{\mathrm{a}}$ & Mean & Median & $\mathrm{AR}^{\mathrm{a}}$ & \\
\hline $\begin{array}{c}\mathrm{CSR} \\
\mathrm{N}=21, \mathrm{~N}=24\end{array}$ & 13.76 & 15 & 26.00 & 12.29 & 12 & 20.38 & 189.00 \\
\hline \multicolumn{8}{|c|}{ Panel B: Internationalisation as \% Assets (FATA) } \\
\hline $\begin{array}{c}\mathrm{CSR} \\
\mathrm{N}=21, \mathrm{~N}=24\end{array}$ & 14.05 & 14 & 26.71 & 12.04 & 12 & 19.75 & $174.00 \dagger$ \\
\hline
\end{tabular}

${ }^{\mathrm{a}}$ AR means average range; $+p<0.10 ;{ }^{*} p<0.05 ;{ }^{* *} p<0.01$.

In addition, we repeated the analysis of the sub-samples with the other internationalisation variables that were considered (Table 5). Here, the results again suggested that the more countries in which the company operates, and when engaged in exports, the greater the commitment to social and environmental issues, being statistically significant in both cases at the $5 \%$ level.

Table 5. Comparative analysis of CSR and Internationalisation (II).

\begin{tabular}{|c|c|c|c|c|c|c|c|}
\hline \multicolumn{8}{|c|}{ Panel A: Internationalisation as Number of Countries (COUNTRIES) } \\
\hline \multirow{2}{*}{ Variables } & \multicolumn{3}{|c|}{ High Internationalisation } & \multicolumn{3}{|c|}{ Low Internationalisation } & \multirow{2}{*}{ Mann-Whitney L } \\
\hline & Mean & Median & $\mathrm{AR}^{\mathrm{a}}$ & Mean & Median & $\mathrm{AR}^{\mathrm{a}}$ & \\
\hline $\begin{array}{c}\text { CSR } \\
\mathrm{N}=29, \mathrm{~N}=32\end{array}$ & 14.31 & 14 & 36.62 & 12.25 & 12 & 25.91 & $301.00 *$ \\
\hline \multicolumn{8}{|c|}{ Panel B: Internationalisation as Export Activity (EXP_ACT) } \\
\hline $\begin{array}{c}\text { CSR } \\
\mathrm{N}=55, \mathrm{~N}=6\end{array}$ & 13.64 & 13.60 & 32.86 & 9.50 & 9.50 & 13.92 & $62.50 *$ \\
\hline
\end{tabular}

Overall, we confirmed the existence of a positive association between performing CSR activity and achieving company growth with an internationalisation strategy, since there were significant differences in three of the four indicators that were used when creating sub-samples.

Once the general picture became clearer, and in those cases where significant differences were noted (FATA, COUNTRIES, and EXPORT_ACT variables), two of the key stakeholder groups were analysed: employees and shareholders. Even with different indicators, we observed again the positive association between a commitment to CSR and the internationalisation process, between actions targeting employees, the number of countries in which the company is present (COUNTRIES), and if the firm is engaged in export activity (EXPORT_ACT), and also between actions targeting the likely shareholders and investors and the economic indicator (FATA) (Table 6). 
Table 6. Comparative analysis of CSR indicators for Employess and Shareholders and Internationalisation.

\begin{tabular}{|c|c|c|c|c|c|c|c|}
\hline \multicolumn{8}{|c|}{ Panel A: Internationalisation as \% Assets (FATA) } \\
\hline \multirow{2}{*}{ Variables } & \multicolumn{3}{|c|}{ High Internationalisation } & \multicolumn{3}{|c|}{ Low Internationalisation } & \multirow{2}{*}{ Mann-Whitney U } \\
\hline & Mean & Median & $\mathbf{A R}^{\mathrm{a}}$ & Mean & Median & $\mathbf{A R}^{\mathbf{a}}$ & \\
\hline $\begin{array}{c}\text { Employees } \\
\mathrm{N}=21, \mathrm{~N}=24\end{array}$ & 4.90 & 5 & 25.71 & 4.25 & 5 & 20.63 & 195.00 \\
\hline $\begin{array}{l}\text { Shareholders } \\
N=21, N=24\end{array}$ & 3.90 & 4 & 27.10 & 3.21 & 3 & 19.42 & $166.00 *$ \\
\hline \multicolumn{8}{|c|}{ Panel B: Internationalisation as Number of Countries (COUNTRIES) } \\
\hline $\begin{array}{c}\text { Employees } \\
N=29, N=32\end{array}$ & 4.86 & 5 & 35.71 & 4.25 & 5 & 26.73 & 327.50 * \\
\hline $\begin{array}{c}\text { Shareholders } \\
N=29, N=32\end{array}$ & 3.76 & 4 & 33.52 & 3.41 & 3 & 28.72 & 391.00 \\
\hline \multicolumn{8}{|c|}{ Panel C: Internationalisation as Export Activity (EXP_ACT) } \\
\hline $\begin{array}{c}\text { Employees } \\
\mathrm{N}=55, \mathrm{~N}=6\end{array}$ & 4.65 & 5 & 32.31 & 3.50 & 3.50 & 19.00 & $93.00+$ \\
\hline $\begin{array}{l}\text { Shareholders } \\
N=55, N=6\end{array}$ & 3.60 & 3 & 31.28 & 3.33 & 3.50 & 28.42 & 149.50 \\
\hline
\end{tabular}

\section{Conclusions}

The main purpose of this research was to study two important competitive and corporate strategies: CSR and internationalisation. Thus, we examined their concepts and characteristics before conducting a descriptive analysis of Spanish listed companies. CSR currently plays a significant role in the business world, with society being increasingly aware of companies' socially responsible behavior. Similarly, internationalisation strategy is relevant due to the globalised world in which most companies operate.

From the review of the literature, we concluded that both strategies are related. Companies with a higher degree of internationalisation might seek to implement more CSR activities and initiatives because of their greater visibility (Hah and Freeman 2013) and availability of funds (Dahan et al. 2006), with the aim of mitigating risk (Mithani 2017) and better responding to the expectations of different stakeholders (Aguilera-Caracuel et al. 2015). Also, more socially responsible companies can increase their degree of internationalisation by leveraging their good name and reputation, facilitating entering new markets and countries (Zeng et al. 2013), and relying on their potential to better adapt to new scenarios (Bansal 2005).

Considering the previous arguments and the potentially bidirectional relationship between CSR and internationalisation, some implications can be highlighted. When developing theoretical models in order to explain the determinants of internationalisation strategy (CSR), social and environmental concepts or variables (internationalisation issues) ought to be included as they could be conditioning such decisions or their effects. Similarly, with regard to methodological aspects, future empirical models, particularly those trying to analyse causality between CSR and internationalisation, should apply adequate techniques in order to control for the endogeneity inherent in the model.

The results of the descriptive analyses seem to suggest a positive relationship between CSR and internationalisation, when considering the weight of assets abroad. With this internationalisation proxy, the results show a positive association between the level of internationalisation and socially responsible behavior in companies. However, no significant correlation was found when the percentage of foreign sales was taken as a proxy. Given the relationship of foreign sales with the entry method that was used by the company (Pla and León 2004), perhaps this factor needs to be considered if we are to find a significant relationship. A positive relationship between CSR and internationalisation, in terms of the 
number of countries and whether companies have export activity, was observed. We found that the increase in social commitment input is commensurate with the growth in the number of countries where the company operates, provided that the company is engaged in export activity. Finally, a positive relationship between CSR, when considering activities targeting employees and shareholders, and internationalisation was suggested. With employees, in a context marked by diversity due to a multi-country presence, developing socially responsible practices can be motivational, contributing to better performance. In terms of shareholders, particularly focusing on issues around transparency, in companies with the largest assets abroad, communication with shareholders appears to be key, given that outputs from their investment decisions may be more remote.

After conducting the analysis, we confirmed that, in general terms, there is a positive relationship between CSR and internationalisation. Thus, they both are mutually beneficial strategies that are being increasingly implemented in major corporations, and which, in most cases, may favor these companies' financial results. This positive link between CSR and internationalisation is consistent with the results of the few previous empirical studies (Aguilera-Caracuel et al. 2011, 2014; Zeng et al. 2013).

Some practical implications can be drawn from our results. Given the positive association between both strategies, CSR and internationalisation, a coordinated decision-making process within a company would be desirable. In the context of a CSR department, for example, managers should be particularly aware of the company's image or reputation in the different markets where it operates. This involvement would be justified in order to guarantee that the efforts of the firm's social and environmental policies are well focused and implemented. Also, within an international or export department, it could be recommended for managers to broaden their perspectives, going beyond marketing tools and sales estimations. Thus, capitalising upon a sound and well recognised socially responsible pattern by the firm might be a profitable and sustainable strategy when entering a new market.

Even though this paper contributes to the study of the relationship between CSR and internationalisation strategies, it has some limitations that can be addressed by future lines of work. Firstly, with regard to the methodology, only descriptive analyses were conducted. In the future, regression analysis might be considered for the purpose of studying the causality between both strategies. Similarly, longitudinal databases with information over a long period of time or more sophisticated analyses/methodologies that allow for us to control by firm characteristics would help the study of internationalisation as a process. Secondly, to achieve a greater understanding of internationalisation and CSR, it would be helpful to consider the different methods of entering foreign markets, given that they entail major differences in terms of the resource allocation needed and the potential for monitoring the process. It might also be of interest to learn whether the international competition approaches that companies may take could similarly affect how CSR activity is conducted. Finally, companies from other countries could be included to analyse the possible influence of the institutional framework on the relationship between companies' international performance and their CSR activity.

Author Contributions: J.-L.G.-D. and L.C.-G. have developed the theoretical framework and they both have selected the variables and carried out the analyses. C.F.-G. has collected information and also helped develop the theoretical framework.

Funding: The authors acknowledge the funding received from the Project ECO2015-63880-R from the Ministerio de Economía y Competitividad. They also acknowledge funding from Project ECO2015-69058-R of Spanish Ministry of Economy and Competitiveness (Spain).

Conflicts of Interest: The authors declare no conflict of interest. 


\section{References}

Aguilera-Caracuel, Javier, Mán Ángeles Escudero Torres, Nuria Esther Hurtado Torres, and María Dolores Vidal Salazar. 2011. La influencia de la diversificación y experiencia internacional en la estrategia medioambiental proactiva de las empresas. Investigaciones Europeas de Dirección y Economía de la Empresa 17: 75-91.

Aguilera-Caracuel, Javier, Blanca Luisa Delgado Márquez, Vidal Salazar, and María Dolores. 2014. Influencia de la internacionalización en el desempeño social de las empresas. Cuadernos de Gestión 14: 15-31. [CrossRef]

Aguilera-Caracuel, Javier, Jaime Guerrero-Villegas, María Dolores Vidal-Salazar, and Blanca L. Delgado-Márquez. 2015. International cultural diversification and corporate social performance in multinational enterprises: The role of slack financial resources. Journal Management International Review 55: 323-53. [CrossRef]

Allouche, José, and Patrice Laroche. 2005. A meta-analytical investigation of the relationship between corporate social and financial performance. Revue de Gestion dess Ressources Humaines 57: 18-41.

Antonacopoulou, Elena P., and Jérôme Meric. 2005. From power to knowledge relationships: Stakeholder interactions as learning partnerships. In Stakeholders and Corporate Social Responsibility: European Perspectives. Edited by M. Bonnafous-Boucher and Y. Pesqueux. London: Macmillan, pp. 125-47.

Aw, B-Y., and Amy Ruey-meng Hwang. 1995. Productivity and the export market: A firm-level analysis. Journal of Development Economics 47: 313-32. [CrossRef]

Aw, Bee Yan, Sukkyun Chung, and Mark J. Roberts. 2000. Productivity and turnover in the export market: Micro evidence from Taiwan and South Korea. The World Bank Economic Review 14: 65-90. [CrossRef]

Bagnoli, Mark, and Susan G. Watts. 2003. Selling to socially responsible consumers: Competition and the private provision of public goods. Journal of Economics E Management Strategy 12: 419-45.

Bansal, Pratima. 2005. Evolving sustainably: A longitudinal study of corporate sustainable. Strategic Management Journal 26: 197-218. [CrossRef]

Barkema, Harry G., and Freek Vermeulen. 1998. International expansion through start-up or acquisition: A learning perspective. Academy of Management Journal 41: 7-26.

Barnett, Michael L. 2007. Stakeholder influence capacity and the variability of financial returns to corporate social responsibility. Academy of Management Review 32: 794-816.

Barnett, Michael L. 2016. The business case for corporate social responsibility. A critique and an indirect path forward. Business \& Society, 1-24. [CrossRef]

Barney, Jay. 1991. Firm resources and sustained competitive advantage. Journal of Management 17: 99-121. [CrossRef]

Bernard, Andrew B., and J. Bradford Jensen. 1999. Exceptional exporter performance: Cause, effect, or both? Journal of International Economics 47: 1-25. [CrossRef]

Bernard, Andrew B., and Joachim Wagner. 1997. Exports and success in German manufacturing. Weltwirtshaftliches Archiv 133: 134-57. [CrossRef]

Bernard, Andrew B., J. Bradford Jensen, and Robert Z. Lawrence. 1995. Exporters, jobs and wages in US Manufacturing, 1976-1987. The Brooking Papers on Economic Activity: Microeconomics 1995: 67-112. [CrossRef]

Besley, Timothy, and Maitreesh Ghatak. 2007. Retailing public goods: The economics of corporate social responsibility. Journal of Public Economics 91: 1645-63. [CrossRef]

Bondy, Krista, Jeremy Moon, and Dirk Matten. 2012. An institution of corporate social responsibility (CSR) in multi-national companies (MNCs): Form and implications. Journal of Business Ethics 111: 281-99. [CrossRef]

Camisón, César, and Ana Villar-López. 2010. Effect of SMEs' international experience on foreign intensity and economic performance: The mediating role of internationally exploitable assets and competitive strategy. Journal of Small Business Management 48: 116-51. [CrossRef]

Campbell, Joanna Tochman, Lorraine Eden, and Stewart R. Miller. 2012. Multinationals and corporate social responsibility in host countries: Does distance matter? Journal of International Business Studies 43: 84-106. [CrossRef]

Carrión Maroto, Juan. 2007. Estrategia: De la Visión de Acción. Madrid: ESIC editorial.

Carroll, Archie B. 1991. The pyramid of corporate social responsibility: Toward the moral management of organizational stakeholders. Business Horizons 34: 39-48. [CrossRef]

Carroll, Archie B. 1999. Corporate social responsibility: Evolution of a definitional construct. Business and Society 38: 268-95. [CrossRef] 
Carroll, Archie, and Ann Buchholtz. 2006. Business and Society: Ethics and Stakeholder Management, 6th ed. Mason: Thomson South-Western.

Chan, Ricky YK, and Katherine HY Ma. 2016. Environmental Orientation of Exporting SMEs from an Emerging Economy: Its Antecedents and Consequences. Management International Review 56: 597-632. [CrossRef]

Chow, Wing S., and Yang Chen. 2012. Corporate sustainable development: Testing a new scale based on the mainland Chinese context. Journal of Business Ethics 105: 519-33. [CrossRef]

Clarkson, Max E. 1995. A stakeholder framework for analyzing and evaluating corporate social performance. Academy of Management Review 20: 92-117. [CrossRef]

Cochran, Philip L. 2007. The evolution of corporate social responsibility. Business Horizons 50: 449-54. [CrossRef]

Huerta, Patricia, Sergio Contreras, Liliana Pedraja, and José Navas. 2015. Influencia del grado de internacionalización sobre los resultados empresariales. Revista de Ciencias Estratégicas 24: 53-71.

Correa-López, M., and R. Doménech. 2012. La internacionalización de las empresas españolas. Documentos de Trabajo BBVA Research, December 29.

Crouch, Colin. 2006. Modelling the firm in its market and organizational environment: Methodologies for studying corporate social responsibility. Organization Studies 27: 1533-51. [CrossRef]

Dahan, Nicolas, Jonathan Doh, and Terrence Guay. 2006. The role of multinational corporations in transnational institution building: A policy network perspective. Human Relations 59: 1571-600. [CrossRef]

Dahlsrud, Alexander. 2008. How corporate social responsibility is defined: An analysis of 37 definitions. Corporate Social Responsibility and Environmental Management 15: 1-13. [CrossRef]

Daily, Catherine M., S. Trevis Certo, and Dan R. Dalton. 2000. International experience in the executive suite: The path to prosperity? Strategic Management Journal 21: 515-23. [CrossRef]

Daniels, John D., and Jeffrey Bracker. 1989. Profit performance: Do foreign operations make a difference? Management International Review 29: 46-56.

Delgado, Miguel A., Jose C. Farinas, and Sonia Ruano. 2002. Firm productivity and export markets: A non parametric approach. Journal of International Economics 57: 397-422. [CrossRef]

Donaldson, Thomas, and Lee E. Preston. 1995. The stakeholder theory of the corporation: Concepts, evidence, and implications. Academy of Management Review 20: 65-91. [CrossRef]

Eisenhardt, Kathleen M., and Jeffrey A. Martin. 2000. Dynamic capabilities: What are they? Strategic Management Journal 21: 1105-22. [CrossRef]

Escuela de Estrategia Empresarial. 2014. Qué es la Internacionalización de las Empresas? Available online: https: / / www.escueladeestrategia.com/que-es-la-internacionalizacion-de-empresas / (accessed on 8 April 2018).

European Parliament. 2013. Report of the Committee on Employment and Social Affairs on Corporate Social Responsibility: Promoting society's interests and a route to sustainable and inclusive recovery (2012/2097(INI)). Available online: https: / / eur-lex.europa.eu/LexUriServ/LexUriServ.do?uri=COM:2013: 0207:FIN:EN:PDF (accessed on 29 September 2018).

Farinas, José C., and Ana Martín-Marcos. 2007. Exporting and economic performance: Firm-level evidence of Spanish manufacturing. The World Economy 30: 618-46. [CrossRef]

Fernández López, María. 2016. Responsabilidad Social Corporativa Estratégica de los Recursos Humanos Basada en alto Compromiso y Resultados Organizativos: Un Modelo Integrador. Ph.D. thesis, Universidad Complutense de Madrid, Madrid, Spain. Available online: http:/ / eprints.ucm.es/40615/1/T38184.pdf (accessed on 8 April 2018).

Fernández, Zulima, and María J. Nieto. 2005. Internationalization strategy of small and medium-sized family businesses: Some influential factors. Family Business Review 18: 77-89. [CrossRef]

Fombrun, Charles, and Mark Shanley. 1990. What's in a name? Reputation building and corporate strategy. Academy of Management Journal 33: 233-58.

Forética. 2015. Informe Forética 2015 Sobre el Estado de la RSE en España. Ciudadano Consciente, Empresas Sostenibles. Available online: http://foretica.org/informe_foretica_2015.pdf (accessed on 29 September 2018).

Freeman, R. Edward. 1984. Strategic Management: A Stakeholder Approach. Boston: Pitman.

Freeman, R. Edward, Jeffrey S. Harrison, Andrew C. Wicks, Bidhan L. Parmar, and Simone De Colle. 2010. Stakeholder Theory: The State of the Art. Cambridge: Cambridge University Press.

Galbreath, Jeremy. 2006. Does primary stakeholder management positively affect the bottom line? Some evidence from Australia. Management Decision 44: 1106-21. [CrossRef] 
García, Francisco, and Lucía Avella Camarero. 2008. La influencia de la exportación sobre los resultados empresariales: Análisis de las pymes manufactureras españolas en el período 1990-2002. Revista Europea de Dirección y Economía de la Empresa 17: 85-104.

García-Canal, Esteban, Mauro Guillén, and Ana Valdés-Llaneza. 2012. La internacionalización de la empresa española. Perspectivas empíricas. Papeles de Economía Española 132: 64-81.

Garriga, Elisabet, and Domènec Melé. 2004. Corporate social responsibility theories: Mapping the territory. Journal of Business Ethics 53: 52-71. [CrossRef]

Geppert, Mike, Dirk Matten, and Peter Walgenbach. 2006. Transnational institution building and the multinational corporation: An emerging field of research. Human Relations 59: 1451-65. [CrossRef]

Geringer, Michael J., Paul W. Beamish, and Richard C. DaCosta. 1989. Diversification strategy and internationalization: Implications for MNE performance. Strategic Management Journal 10: 109-19. [CrossRef]

González, Belén, Cristina López-Duarte, and Marta María Vidal-Suárez. 2013. Cooperación e internacionalización: El caso de ALSA. Revista de Historia Industrial 55: 170-72.

Gregorio, Raúl. 2013. Herramientas de Gestión para la Responsabilidad Social Corporativa. Trabajo fin de Máster. Universidad de Valladolid. Available online: https:/ /uvadoc.uva.es/bitstream/10324/6500/1/TFM-P-109. pdf (accessed on 10 April 2018).

Guerras, Luis Ángel, and José Emilio Navas. 2015. La Dirección Estratégica de la Empresa: Teoría y Aplicaciones, 5th ed. Madrid: Thomson Reuters-Civitas.

Hah, Kristin, and Susan Freeman. 2013. Multinational enterprise subsidiaries and their CSR: A conceptual framework of the management of CSR in smaller emerging economies. Journal of Business Ethics 122: 125-36. [CrossRef]

Hillman, Amy J., and Gerald D. Keim. 2001. Source shareholder value, stakeholder management, and social issues: What's the bottom line? Strategic Management Journal 22: 125-39. [CrossRef]

Husted, Bryan W., and David B. Allen. 2007. Strategic corporate social responsibility and value creation among large firms. lessons from the Spanish experience. Long Range Planning 40: 594-610. [CrossRef]

Infante, Rivas H. 2015. Responsabilidad Social Corporativa o Empresarial. Gestiopolis. Available online: https: / / www.gestiopolis.com/responsabilidad-social-corporativa-o-empresarial/ (accessed on 9 April 2018).

Jamali, Dima. 2010. The CSR of MNC subsidiaries in developing countries: Global, local, substantive or diluted. Journal of Business Ethics 93: 181-200. [CrossRef]

Jones, Thomas M. 1995. Instrumental stakeholder theory: A synthesis of ethics and economics. Academy of Management Review 20: 404-37. [CrossRef]

Keinert, Christina. 2008. Corporate Social Responsibility as an International Strategy. Contributions to Economics. Berlin: Springer Company.

Key, Susan. 1999. Toward a new theory of the firm: A critique of stakeholder "theory". Management Decision 37: 317-28. [CrossRef]

King, Andrew A., and Christopher L. Tucci. 2002. Incumbent entry into new market niches: The role of experience and managerial choice in the creation of dynamic capabilities. Management Science 48: 171-86. [CrossRef]

Laudal, Thomas. 2011. Drivers and barriers of CSR and the size and internationalization of firms. Social Responsibility Journal 7: 234-56. [CrossRef]

Lee, Ho-Uk, and Jong-Hun Park. 2006. Top team diversity, internationalization and the mediating effect of international alliances. British Journal of Management 17: 195-213. [CrossRef]

López-Duarte, Cristina, and Esteban García-Canal. 2007. Stock market reaction to foreign direct investments: Interaction between entry mode and FDI attributes. Management International Review 47: 393-422. [CrossRef]

Madhok, Anoop. 1997. Cost, value and foreign market entry mode: The transaction and the firm. Strategic Management Journal 18: 39-61. [CrossRef]

Maignan, Isabelle, and David A. Ralston. 2002. Corporate social responsibility in Europe and the US: Insights from businesses self-presentations. Journal of International Business Studies 33: 497-514. [CrossRef]

Majocchi, Antonio, and Antonella Zucchella. 2005. Internationalization and performance. International Small Business Journal 21: 249-60. [CrossRef]

Malhotra, Naresh K. 1981. A scale to measure self-concepts, person concepts and product concepts. Journal of Marketing Research 18: 456-64. [CrossRef]

Manner, Mikko H. 2010. The impact of CEO characteristics on corporate social performance. Journal of Business Ethics 93: 53-72. [CrossRef] 
Margolis, Joshua D., Hillary Anger Elfenbein, and James P. Walsh. 2007. Does It Pay to Be Good? A Meta-Analysis and Redirection of Research on the Relationship between Corporate Social and Financial Performance. Working Paper, Harvard Business School, Boston, MA, USA.

Matten, Dirk, and Jeremy Moon. 2008. 'Implicit' and 'explicit' CSR: A conceptual framework for a comparative understanding of corporate social responsibility. Academy of Management Review 33: 404-24. [CrossRef]

McWilliams, Abagail, and Donald Siegel. 2001. Corporate social responsibility: A theory of the firm perspective. Academy of Management Review 26: 117-27. [CrossRef]

Mishina, Yuri, Emily S. Block, and Michael J. Mannor. 2012. The path dependence of organizational reputation: How social judgment influences assessments of capability and character. Strategic Management Journal 33: 459-77. [CrossRef]

Mitchell, Ronald K., Bradley R. Agle, and Donna J. Wood. 1997. Toward a theory of stakeholder identification and salience: Defining the principle of who and what really counts. Academy of Management Review 22: 853-886. [CrossRef]

Mithani, Murad A. 2017. Liability of foreignness, natural disasters, and corporate philanthropy. Journal of International Business Studies 48: 941-63. [CrossRef]

Nummela, Niina, Kaisu Puumalainen, and Sami Saarenketo. 2005. International growth orientation of knowledge-intensive SMEs. Journal of International Entrepreneurship 3: 5-18. [CrossRef]

Orlitzky, Marc, Frank L. Schmidt, and Sara L. Rynes. 2003. Corporate social and financial performance: A meta-analysis. Organization Studies 24: 403-41. [CrossRef]

Pant, Anirvan, and J. Ramachandran. 2017. Navigating identity duality in multinational subsidiaries: A paradox lens on identity claims at Hindustan Unilever 1959-2015. Journal of International Business Studies 48: 664-92. [CrossRef]

Pedrero, Y. 2014. La estrategia de Internacionalización: Análisis Comparativo de los Mecanismos de Entrada en Mercados Exteriores de seis Empresas que Operan en Diferentes Sectores de la Economía. Trabajo fin de Master. Universidad de Barcelona. pp. 31-35. Available online: http:/ / diposit.ub.edu/dspace/bitstream/ 2445/66261/1/TFM_MOI_Pedrero-Yolanda-jun2015.pdf (accessed on 12 April 2018).

Peng, Mike W., and Andrew Delios. 2006. What determines the scope of the firm over time and around the world? An Asia Pacific Perspective. Asia Pacific Journal of Management 23: 385-405. [CrossRef]

Pla, José, and A. Cobos. 2002. La aceleración del proceso de internacionalización de la empresa: El caso de las international new ventures. ICE Sector Exterior Español 802: 9-22.

Pla, José, and Fidel León. 2004. Dirección de Empresas Internacionales. Madrid: Pearson Educación, p. 5.

Porter, Michael E., and Mark R. Kramer. 2006. The link between competitive advantage and corporate social responsibility. Harvard Business Review 84: 78-92. [PubMed]

Porter, Michael E., and Mark R. Kramer. 2011. Creating Shared Value. Harvard Business Review 89: 62-77.

Becerra, Puerto, and Doria Patricia. 2010. La globalización y el crecimiento empresarial a través de estrategias de internacionalización. Pensamiento E Gestión 28: 171-95.

Ramirez-Aleson, Marisa, and Manuel Antonio Espitia-Escuer. 2001. The effect of international diversification strategy on the performance of Spanish-Based firms during the period 1991-1995. Management International Review 41: 291-315.

Rivas, Jose Luis, Monika Hamori, and Margarita Mayo. 2009. Board composition and firm internationalization. Academy of Management Proceedings 1: 1-6. [CrossRef]

Rodríguez, Andrea. 2015. Estrategias de Crecimiento en Empresas Multinacionales. Trabajo fin de Grado, Universidad de León. Available online: https://buleria.unileon.es/bitstream/handle/10612/4050/ 71520095P_GCI_Diciembre14.pdf.pdf?sequence=1 (accessed on 7 April 2018).

Sánchez, Leticia A. Pérez-Calero, María del Mar Villegas Periñán, and Carmen Barroso Castro. 2013. El consejo de administración y la toma de decisiones internacionales. Esic Market Economics and Business Journal 44: 83-107.

Sanders, WM Gerard, and Mason A. Carpenter. 1998. Internationalization and firm governance: The roles of CEO compensation, top team composition and board structure. Academy of Management Journal 41: 158-78.

Santonja, Aldo Olcese, Juan Alfaro, and Míguel Ángel Rodríguez. 2008. Manual de la Empresa Responsable y Sostenible. Conceptos y Herramientas de la Responsabilidad Social Corporativa o de la Empresa. Madrid: McGraw-Hill. 
Sen, Sankar, Chitra Bhanu Bhattacharya, and Daniel Korschun. 2006. The role of corporate social responsibility in strengthening multiple stakeholder relationships: A field experiment. Journal of the Academy of Marketing Science 34: 158-66. [CrossRef]

Sharma, Suparn, Joity Sharma, and Arti Devi. 2009. La responsabilidad social de las empresas: El papel clave de la gestión de recursos humanos. Business Intelligence Journal 2: 205-13.

Smith, Katherine Taken, Murphy Smith, and Kun Wang. 2010. Does brand management of corporate reputation translate into higher market value? Journal of Strategic Marketing 18: 201-21. [CrossRef]

Spence, A. M. 1974. Market Signaling: Information Transfer in Hiring and Related Processes. Cambridge: Harvard University Press.

Sullivan, Daniel. 1994. Measuring the degree of internationalization of a firm. Journal of International Business Studies 25: 325-42. [CrossRef]

Surroca, Jordi, Josep A. Tribó, and Sandra Waddock. 2010. Corporate responsibility and financial performance: The role of intangible resources. Strategic Management Journal 31: 463-90. [CrossRef]

Thomas, Douglas E., and Lorraine Eden. 2004. What is the shape of the, multinationality-performance relationship? Multinational Business Review 12: 89-110. [CrossRef]

Tseng, Jou-ying, and Chwo-Ming Joseph Yu. 1991. Export of industrial goods to Europe: The case of large Taiwanese firms. European Journal of Marketing 25: 51-63. [CrossRef]

van Oosterhout, Hans, and Pursey P. M. A. R. Heugens. 2009. Much ado about nothing: A conceptual critique of corporate social responsibility. In The Oxford Handbook of Corporate Social Responsibility. Edited by Andrew Crane, Dirk Matten, Abagail McWilliams, Jeremy Moon and Donald S. Siegel. Oxford: Oxford University Press, pp. 197-223.

Vila, Natalia, and Inés Küster. 2015. Conduce la internacionalización al éxito de una empresa familiar? Aplicación al sector textil. INNOVAR. Revista de Ciencias Administrativas y Sociales 25: 43-51. [CrossRef]

Wallin Andreassen, Tor, and Bodil Lindestad. 1998. Customer loyalty and complex services: The impact of corporate image on quality, customer satisfaction and loyalty for customers with varying degrees of service expertise. International Journal of Service Industry Management 9: 7-23. [CrossRef]

Wang, Taiyuan, and Pratima Bansal. 2012. Social responsibility in new ventures: Profiting from a long-term orientation. Strategic Management Journal 33: 1135-53. [CrossRef]

Wang, Qian, Junsheng Dou, and Shenghua Jia. 2016. A meta-analytic review of corporate social responsibility and corporate financial performance: The moderating effect of contextual factors. Business $\mathcal{E}$ Society 55: 1083-121.

Wan-Jan, Wan Saiful. 2006. Defining corporate social responsibility. Journal of Public Affairs 6: 176-84. [CrossRef] Wernerfelt, Birger. 1984. A resource-based view of the firm. Strategic Management Journal 5: 171-80. [CrossRef]

Wood, Donna J. 2010. Measuring corporate social performance: A review. International Journal of Management Reviews 12: 50-84. [CrossRef]

$\mathrm{Wu}$, Meng-Ling. 2005. Corporate social performance, corporate financial performance and firm size: A meta-analysis. Journal of American Academy of Business 8: 163-71.

Zeng, Fue, Ji Li, Hong Zhu, Zhenyao Cai, and Pengcheng Li. 2013. How international firms conduct societal marketing in emerging markets an empirical test in China. Management and International Review 53: 841-68.

(C) 2018 by the authors. Licensee MDPI, Basel, Switzerland. This article is an open access article distributed under the terms and conditions of the Creative Commons Attribution (CC BY) license (http:// creativecommons.org/licenses/by/4.0/). 